\title{
ROBERT F. BYRNES
}

\section{Archibald Cary Coolidge: A Founder of Russian Studies in the United States}

Americans have paid relatively little attention to the history of higher education in the United States, and Russian specialists have neglected the history of their own field, even though our foundations strongly affect our qualities as scholarteachers and the circumstances in which we work. One of the most important founding fathers of Russian studies in the United States was Archibald Cary Coolidge, a member of the Department of History at Harvard University from 1893 until his death in 1928, who launched teaching and research concerning Russia and Eastern Europe at Harvard and in many other colleges and universities through those whom he helped train. His high standards helped to ensure that Russian studies would retain his stamp of imagination and distinction from their professional beginning "through the years of great awakening in the American historical world." He contributed significantly to creating the golden age of the Harvard Department of History and to the transformation of Harvard from a small New England college into an internationally renowned center for research and instruction. He helped widen the academic horizons of Harvard and of his profession by introducing study of other parts of the world as well-particularly the Middle East and Asia-and of modern diplomatic history. He began the transformation of Harvard's library into one of the world's great collections and inspired men in other institutions to emulate him. His activities in the American Historical Association, in the creation of Foreign Affairs, and in service to the government in times of emergency exerted a powerful influence upon American scholarship and opinion on international politics, and helped define the terms upon which scholars serve Washington.

Coolidge was not an outstanding scholar and clearly lacked the brilliance as a writer of his older colleagues in American history, or of Charles Homer Haskins or Frederick Jackson Turner, whom he helped bring to Harvard. He lacked the personal ambition a publishing scholar must have. Moreover, his mind was too restless and his interests too varied for him to concentrate upon scholarship. He was in some ways "an intellectual huritsman riding to the hounds." George Santayana, an associate and careful observer of Coolidge, wrote that his mind, "while well-stocked and perfectly reasonable, seemed somehow thin, as if there were no central sun in it, no steady light and center of gravity."1

Nevertheless, Coolidge produced three important books. The best known of these, The United States as a World Power (published in 1908), is a collection

1. George Santayana, Persons and Places, vol. 2 (New York, 1963), p. 162.

In preparing this paper, I have benefited greatly from the opportunity for research and writing which the Netherlands Institute for Advanced Study has provided. An earlier version of this paper was presented at the annual meeting of the American Historical Association in Washington, D.C., on December 28, 1976. 
of lectures he gave at the Sorbonne in 1906-7. This volume was reprinted ten times before Coolidge died, was published again in 1971, and was translated into French, German, and Japanese. His second book, The Origins of the Triple Alliance (published in 1917), was the product of a series of lectures he gave at the University of Virginia in 1916; a second edition appeared in 1926. Coolidge's final volume, which appeared in 1927, was an outstanding collection of three essays which he wrote between 1912 and 1920 plus seven which he published in Foreign Affairs between 1922 and 1927. Written in a clear, detached, and direct style, these volumes reveal wide knowledge, insight, and objectivity. He supplemented them with sixteen scholarly articles and a flood of popular essays and book reviews. In addition, he edited three important books, one a revision of Sir Edward Creasy's famous History of the Ottoman Turks, which has been frequently reprinted, and which served as a basic book in many history courses until after the Second World War. ${ }^{2}$

Coolidge first won acclaim at Harvard as a teacher of undergraduates, despite the fact that he was undramatic, precise, and sober and expected serious and sustained work from his students. His principal achievement in the college was his introduction of the basic Western European Civilization course, History 1 , which retained the same framework until after the Second World War. Coolidge established the basic principles-two concise, factual lectures, which established the narrative skeleton, and one discussion section each week, a brief weekly examination, heavy use of atlases and maps, extensive reading from primary and secondary sources, and encouragement to use books in French and German in preparing term papers. As taught first by Coolidge and later by Roger B. Merriman, Haskins, and Michael Karpovich, History 1 was one of the most celebrated courses at Harvard for several decades. ${ }^{3}$

The energy and devotion Coolidge gave to this freshman course reflect his interest in undergraduate teaching during his first ten or twelve years at Harvard. He lived in an undergraduate dormitory through 1916, and he formed close relationships with many members of each class. He served as a member of the administrative board of Harvard College from 1897 through 1905. He was chairman of the Committee on the Regulation of Athletic Sports from 1899 to 1905 , a critical period because of the national wave of criticism of football. He even joined the Harvard crew as its examination proctor during the week before the annual race with Yale in 1897. Above all, through his work both in and out of the classroom, he excited many Harvard undergraduates into an enduring interest in knowing and understanding European and non-Western history, and in reading and even in collecting books. ${ }^{4}$

2. Archibald Cary Coolidge, The United States as a World Power (New York, 1908; St. Clair Shores, Mich., 1971); Coolidge, Origins of the Triple Alliance: Three Lectures (New York, 1917; 1926); Coolidge, Ten Years of War and Peace (New York, 1927); Sir Edward S. Creasy, Turkey, revised and ed. Archibald Cary Coolidge and W. Harold Claflin (Philadelphia, 1907); Alfred Pribram, The Secret Treaties of Austria-Hungary, 1879-1914, 2 vols., ed. Archibald Cary Coolidge (Cambridge, 1920-21; New York, 1967); Coolidge and Edward Channing, eds., The Barrington-Bernard Correspondence and Illustrative Matter, 1760-1770 (Cambridge, Mass., 1912). Some of Coolidge's publications are listed in Harold Jefferson Coolidge and Robert Howard Lord, Archibald Cary Coolidge: Life and Letters (Boston, 1932), pp. 354-55.

3. Harvard University, Department of History, List of References in History I (1910).

4. Archibald Cary Coolidge, "Professional Coaches: From Report of the Athletic Committee for 1904-1905," Harvard Graduates' Magazine, March 1906, pp. 329-95; Hamilton 
After his first decade at Harvard, Coolidge devoted increasing amounts of time to attracting and training outstanding graduate students. Among the approximately twenty young men who received their Ph.D.'s under his direction, three-Sidney B. Fay, William L. Langer, and Dexter Perkins-later became presidents of the American Historical Association. The men who worked with him in History 1, or who received their degrees under his supervision, introduced instruction concerning Russia, Eastern Europe, the Near East and Northern Africa, European diplomatic history, and modern European history into colleges and universities throughout the United States. Coolidge's influence thus flowed throughout the historical profession.

Coolidge is probably best known for his work as director of the Harvard University library from 1910 through 1928, a period during which it became one of the best organized libraries for scholars and students as well as one of the great libraries of the world. Coolidge had a passionate interest in books and in improving the library from the time he was appointed to the faculty. Above all, he had a vision of what a great library should be. Even when traveling during a sabbatical leave in 1906, before he became a member of the Library Council, he wrote from India describing the kind of library Harvard needed and outlined some of the necessary first steps. He then convinced President Lowell, the Harvard Corporation, and a number of alumni to help the university achieve this goal. $^{5}$

Coolidge's second inner circle was his profession and its instrument, the American Historical Association, of which he was an early life member. $\mathrm{He}$ attended almost every annual meeting over a period of thirty-five years; he presented papers at four sessions and participated in four other programs. Besides numerous reviews, he published three articles in the American Historical Review. He served full terms on the executive council of the Association and on the Board of Editors of the Review, and he was active on several significant committees.

The third circle of Coolidge's life was the Department of State, through which he and his students acquired important understanding of the forces affecting American foreign policy and international politics. As a graduate student, Coolidge had considered a diplomatic career. Between 1890 and 1893, he worked briefly in the American legations in St. Petersburg, Vienna, and Paris. In 1900,

Fish Armstrong, Peace and Counterpeace: From Wilson to Hilter (New York, 1971), p. 186; Ephraim Emerton and Samuel Eliot Morison, "History, 1838-1929," in Samuel Eliot Morison, ed., The Development of Harvard University since the Inauguration of President Eliot, 1869-1929 (Cambridge, Mass., 1930), pp. 162 and 170; "The New Haven Meeting of the American Historical Association," American Historical Review, 4, no. 3 (April 1899): 413; Coolidge and Lord, A. C. Coolidge, pp. 62-63; William Bentinck-Smith, Building a Great Library: The Coolidge Years at Harvard (Cambridge, Mass., 1976), pp. 6-9; Roger B. Merriman, "Archibald Cary Coolidge," Harvard Graduates' Magazine, June 1928, pp. 551-52.

5. Archibald Cary Coolidge, "The Harvard College Library," Harvard Graduates" Magasine, September 1915, pp. 23-31; Bentinck-Smith, Building a Great Library, pp. 42-66, 204; Harvard University, Library, Harvard University Library, 1638-1968 (Cambridge, Mass., 1969), pp. 18-19; Thomas Franklin Currier, “Archibald Cary Coolidge," Library Journal, 53, no. 3 (February 1928) : 131-33; William Coolidge Lane, "The Harvard College Library, 1877-1928," in Morison, The Development of Harvard University, pp. 618-19; Alfred C. Potter, The Library of Harvard University. Descriptive and Historical Notes (Cambridge, Mass., 1934), pp. 172-78. 
he sought the legation in Constantinople when Oscar Strauss resigned, but he wanted the post for only two or three years so that he could improve his knowledge of Ottoman history and complete two major studies-the biography of Suleiman the Magnificent on which he was then engaged, and a history of Constantinople, on which he worked intermittently throughout his life. He later declined a number of high posts in the department. Presidents Taft and Wilson both considered appointing him secretary of state, but neither they nor other statesmen offered him truly critical positions.

Throughout his professional life, Coolidge remained in frequent contact with officials in the State Department, which he served from 1917 through 1919, and for which he, in effect, directed a small school for training future diplomats. He opposed the creation of special schools for this purpose, but believed that educating young men who could lead in various areas of life, including the government, was one of the main functions of a Harvard professor. More than thirty of his students found satisfying careers in the Foreign Service, twelve became senior ambassadors, and two served as undersecretaries of state. ${ }^{6}$

Finally, in May 1919, Coolidge helped to found the Council on Foreign Relations. In 1922, he became the first editor of the Council's journal, Foreign Affairs. During the next six years, through his imagination in identifying critical issues and in persuading competent statesmen and scholars to write about them, Coolidge made Foreign Affairs an outstanding American quarterly in the field of international politics.

Coolidge was born in Boston in 1867 into a cultivated and dignified family which traced its origins back to the Bay Colony in the 1630s and to Thomas Jefferson in Virginia. His family led a simple and austere but comfortable life on income inherited from the Salem and Boston shipping trades. As one of five sons in a close Brahmin family, he grew up in "the most homogeneous, selfcentered, and complacent community in the United States," one which still considered itself "the hub of the solar system." His father was especially interested in geography, trade, and international politics, and the family frequently traveled in western Europe when Coolidge was a boy. Coolidge made fifteen trips to Europe before 1908. A youngster with an inquiring mind and a particular interest in military history, Coolidge was drawn-apparently in part by family interests-into a concern for travel and for study of exciting, even exotic areas.

While a sophomore at Harvard, when the annual salary for a full professor was four thousand dollars, Coolidge, along with each of his brothers, received an annual income of eight thousand dollars in trust from his maternal grandfather. This endowment, a generous allowance from his parents, and skillful investments made for him by a shrewd family friend, John F. Moors, enabled Coolidge to follow his interests throughout his life without concern for funds. Thus, he served as a kind of private and generally anonymous foundation to encourage Harvard to make faculty appointments in Russian and other neglected fields. He provided fellowship funds for promising students and made massive and skillful purchases for the Harvard library. In addition, he provided annual

6. Harvard University Archives (hereafter cited as HUA), Archibald Cary Coolidge, diary entry, March 21, 1900; Julian L. Coolidge, diary entry, March 29, 1900; Archibald Cary Coolidge, letter to Allen Dulles, July 25, 1921. 
support for the general administration of the library, especially for the important but unglamorous function of cataloging. When this "almost pathetically modest" man died, he left an estate of slightly more than a million dollars, about half of which went to Harvard for a chair in modern European or Asiatic history, graduate fellowships, and the library. ${ }^{7}$

Coolidge attended private schools before he graduated from Harvard summa cum laude, in 1887, in a class which included James Harvey Robinson and Bernard Berenson, who also exerted great influence upon American intellectual life. Coolidge's interest in Russia and in central and eastern Europe apparently developed after his graduation, when he made a bicycle trip through AustriaHungary. In the fall semester of 1889 , he began to study Russian while he was a student in the Ecole des sciences politiques in Paris. In the fall of 1890, he traveled through Scandinavia into Russia, where he spent six months as a secretary in the American legation in St. Petersburg and a similar period roaming through European Russia, the Caucasus, and Central Asia, on his way to Samarkand. He returned to Paris for another term, studied in Berlin, traveled throughout Europe and then around the world, served three months in the American legation in Vienna, and returned to the United States with a Ph.D. in American constitutional history which he had received in Freiburg-im-Breisgau in 1892. Some of his translations of Nekrasov, Tiutchev, and Pushkin, done during these years, were published in 1895 and later reprinted, indicating that his Russian when he arrived at Harvard in the fall of 1893 may have been as fluent as the German, French, and Italian he had acquired before and during his undergraduate years. ${ }^{8}$

At that time, the Harvard Department of History offered only two courses other than American history, both dealing with the history of Western Europe. During his initial year, Coolidge requested permission to teach a course on northeastern Europe (Denmark, Sweden, Poland, and Russia) from 1453 to 1795. This course was offered for the first time in 1894, for one semester; its title was changed in 1909 to the History of Russia, and it became a full-year course. It remained the basic Russian history course at Harvard for a long time. In 1896, Coolidge introduced a course on the Eastern Question, which he taught in alternate years with his course on Russian history. The following year, he launched a course on European diplomatic history, and in 1904 one on the expansion of Europe. In 1909, he initiated still another course, the Far East in the Nineteenth Century, and in 1920, a full-year course on Europe between 1871 and 1914. In short, Coolidge introduced Russian and East European history in

7. Bentinck-Smith, Building a Great Library, p. 13.

8. Archibald Cary Coolidge, “'The Unknown Strip,' from Nekrasov. 'The Angel,' from Lermontov," Harvard Monthly, 19 (January 1895): 131-35; Archibald Cary Coolidge, "Translations from the Russian," Anglo-Russian Literary Society, Proceedings, no. 14 (February-April 1896), pp. 35-38, no. 15 (May-August 1896), p. 97; Archibald Cary Coolidge, trans., "The Demon," Slavonic Review, 4 (December 1925) : 278-307; Leo Wiener, ed., Anthology of Russian Literature, vol. 2 (New York, 1903), pp. 165-67; Harvard College, Class of 1887, Secretary's Report No. II. 1890 (Melrose, Mass., 1890), p. 19, Secretary's Report No. IV. 1897 (Melrose, Mass., 1897), p. 40; Bernard Pares, "Archibald Cary Coolidge," Slavonic Review, 11 (April 1932): 607-9; Armstrong, Peace and Counterpeace, pp. 191-92; Coolidge and Lord, A. C. Coolidge, pp. 117-38; HUA, Archibald Cary Coolidge, letters to his mother, July 9, July 22, and August 16, 1895; letter to his father, August 16, 1895. 
the framework of expanded instruction concerning Europe and the world, and helped transform the character of the undergraduate curriculum. ${ }^{9}$

After his first decade of teaching-when he believed Harvard had sufficient faculty and library resources to offer Ph.D.'s in modern European historyCoolidge switched his emphasis to training graduate students. The careers of just four of his students demonstrate the impact he has had upon Russian and East European studies. Frank Golder, whose 1909 thesis became the first scholarly book in Russian history to be published by an American, joined Coolidge on the Inquiry, a group of scholars organized in 1917 at Colonel Edward M. House's suggestion to provide President Wilson with accurate information for the peace conference. Golder later served with the American Relief Administration in Russia in 1921, and became the first director of the Hoover Institution. The purchases he made while in the Soviet Union in 1921-23, 1925, and 1927, helped create the foundations for the great Hoover Institution collections on Russia. In the first two years alone, Golder purchased twenty-five thousand volumes and sixty thousand pamphlets and documents. Another Coolidge student, Robert Howard Lord, received his degree in 1910 and immediately assumed responsibility for the Russian history course which Coolidge had taught, as well as for courses in East European and German history. Lord also joined Coolidge on the Inquiry. He exercised great influence in establishing the boundaries of Poland while he served in Paris in 1919 as a member of the American Commission to Negotiate Peace. He remained an outstanding scholar of Poland and of nineteenth-century diplomatic history until he left Harvard in 1926 to become a Catholic priest. A third student was Robert J. Kerner, whom Coolidge persuaded to come to Harvard in 1910 for graduate training. Kerner received his degree in 1914, served with Coolidge on the Inquiry, and in Vienna and Paris with the American Commission to Negotiate Peace, and later helped to make Berkeley one of the strongest American institutions in Russian and East European studies. Finally, Robert Blake, who followed Coolidge by studying at Harvard, Freiburg, and Berlin, and who received his degree in 1916, became America's first native Byzantine scholar and succeeded Coolidge as director of the Harvard University library. ${ }^{10}$

These men, and others whom Coolidge helped educate for service in other academic institutions, all possessed high intellect and deep motivation. In his

9. Carol F. Baird, "Albert Bushnell Hart: The Rise of the Professional Historian," in Paul Buck, ed., Social Sciences at Harvard, 1860-1920 (Cambridge, Mass., 1965), pp. 131-32; Samuel Eliot Morison, "Edward Channing. A Memoir," Proceedings of the Massachusetts Historical Society, 64 (May 1931): 264-69; Roger B. Merriman, Suleiman the Magnificent, 1520-1566 (Cambridge, Mass., 1944), preface; Merriman, "Coolidge," pp. 551-52; Charles M. Andrews, "These Forty Years," American Historical Review, 30, no. 2 (January 1925): 233; Council on Foreign Relations Archives, Hamilton Fish Armstrong, letter to General Tasker H. Bliss, January 28, 1928.

10. Frank A. Golder, Russian Expansion on the Pacific, 1641-1850 (Cleveland, 1914), pp. 6-7; Dexter Perkins, Yield of the Ycars: An Autobiography (Boston, 1969), pp. 29-30, 34-35, 40-41, 118-19; Robert Lee Wolff, "Robert Pierpont Blake, 1886-1950," Dumbarton Oaks Papers, no. 8 (1954), pp. 1-9; Patricia A. Goler, "Robert Howard Lord and the Settlement of Polish Boundaries after World War I" (Ph.D. diss., Boston College, 1957); Coolidge and Lord, A.C. Coolidge, pp. 51 and 67; Emerton and Morison, "History," p. 170; HUA, Bruce C. Hopper, "Archibald Cary Coolidge. The Olympian Teacher," Appleton Chapel, Harvard University, June 5, 1965; University of California, Bancroft Library, Coolidge letters to Robert J. Kerner, February 26, April 2, April 4, 1910; March 20, May 16, 1913; March 31, July 23, 1914; Kerner letter to Coolidge, March 21, 1910. 
seminars, which offered a general European history framework for research, Coolidge provided careful and demanding training. He encouraged his young scholars to develop their intellectual interests and capacities independently. In order to ensure ample opportunity for foreign travel and study, he served on the College Committee on Fellowships and Scholarships from 1907 until his death, invited some students to travel with him on occasion as secretaries or aides, and used his own funds for private grants. He encouraged them to travel throughout Europe, including Russia, whatever their special areas of interest, so that they could acquire understanding of factors such as geography, improve their language facility, familiarize themselves with the libraries, and meet the scholars in their fields who resided in other countries. He even encouraged his students to remain abroad as long as possible, rather than rush home to complete their theses and obtain positions. Lord, for example, spent 1908-10 in Vienna, Berlin, and Moscow. Kerner lived in Prague, Vienna, Moscow, and Berlin from 1912 until the onset of the war in 1914. Blake, who mastered twelve languages, spent 1911-12 in St. Petersburg studying with Professor Michael Rostovtsev, returned to Petrograd for two years (1916-18), and then spent two years in the Caucasus, where he followed Coolidge's example by climbing Mount Ararat.

One of Coolidge's most important students, although he did not complete his Ph.D., was Robert F. Kelley, who graduated from Harvard in 1915, spent the next year in France on a fellowship, and completed his M.A. degree in 1917 (on the diplomatic history of the Crimean War) before he joined the army. Kelley began studying Russian at Harvard and mastered it while serving as a military attaché in Riga after the war. He joined the Department of State in December 1922. From October 1925 until June 1937, he was chief of the Division of East European Affairs, which included Russia. Kelley's ambitions are reminiscent of Coolidge's, for he sought to give the department "the best informed Foreign Office in the world on developments in the Soviet Union, Soviet relations with other countries, and Communist activities. . . ." Kelley initiated the division's large library collection, and it was Kelley who decided, in 1928, that the Department of State-which was unable to attract young men from the universities who knew Russian-should provide intensive study of Russian and of Russia for some of its young diplomats. He therefore assigned George Kennan to Berlin and Riga and Charles Bohlen (who had studied Russian history with Lord as a Harvard undergraduate, and who had enjoyed two early years in Prague) to Paris and Riga for two years of study. This policy, with these and other men, helped provide the Department of State with some of the specialists on Russia it so desperately needed in later years. ${ }^{11}$.

Coolidge also helped reshape parts of the Harvard College faculty. This considerable achievement, within and beyond the Department of History, illustrates both his insight and his authority in the days before foundations and the Office of Education provided financial encouragement. Throughout his years at Harvard, which had less than seventy faculty members and fifteen hundred students when he was appointed, the president retained not only final authority but even the initiative on faculty appointments. Indeed, the Department of His-

11. Harvard College, Class of 1915, Twenty-fifth Anniversary Report (Cambridge, Mass., 1940), pp. 402-4, and Fiftieth Anniversary Report (Cambridge, Mass., 1965), pp. 284 87; Charles E. Bohlen, Witness to History, $1929-1969$ (New York, 1973), pp. 8-13; George F. Kennan, Memoirs, 1915-1950 (Boston, 1967), pp. 23-33, 40, 62, 82-84. 
tory appointed Coolidge after President Charles W. Eliot inquired of Edward Channing (then department chairman) if he could make some use of Coolidge that fall. Coolidge was chairman of the department for less than three years and never served as dean. However, the records of the department, Coolidge's correspondence with Presidents Eliot and Lowell, and his correspondence with future colleagues, all indicate that Coolidge was allowed to act as though he were dean of the faculty. His authority, at least by contemporary academic procedures, may reflect the quality of his mind, his energy, his record of achievement, his close relationships with Eliot and Lowell, the fact that he guaranteed the salary of a new colleague for the first few years, and perhaps even the fact that he always had a secretary, whose salary he paid himself. In any case, he frequently made initial inquiries and even formal offers of appointment, including salaries, within and beyond the Department of History. Coolidge's colleague, Frederick Jackson Turner, believed that Coolidge was responsible for most of the intellectual transformation of Harvard during these years, credit for which ordinarily went to Lowell. ${ }^{12}$

Coolidge's main interest remained the Department of History and strengthening its Russian and East European section. When he became director of the library, he persuaded Lowell to open another position in the department, thus enabling Lord to become an instructor there. In the fall and winter of 1926-27, when it was clear that Lord would not return to Harvard, Coolidge made the senior appointment which ensured superior instruction in Russian history in Harvard for the next thirty years. After learning from the American minister in Prague that George Vernadsky did not speak English, Coolidge invited Michael Karpovich to Harvard for the spring semester of $1927 .^{13}$ This began the Harvard career of Karpovich, whom Coolidge had known for ten years and who has trained more young men and women in Russian history in the United States than any other professor. When Coolidge died in January 1928, his most brilliant student, William L. Langer, who had occasionally substituted for him, was appointed to replace him. Sidney B. Fay, another Coolidge student, then joined the department in 1929 to teach Lord's German history courses. Thus, directly and indirectly, Coolidge helped give Harvard the great strength in Russian history and modern diplomatic history which had always been one of his goals.

Coolidge's insistence that historians master languages led him to introduce instruction in Slavic languages and literatures. In 1896, he employed Leo Wiener to catalog Slavic and other books which he had purchased in Leipzig. He then persuaded President Eliot to begin instruction in Russian by agreeing that he, his father, and his uncle (John Gardner), would pay Wiener's salary as an in-

12. Ray Allen Billington, ed., Dear Lady: The Letters of Frederick Jackson Turner to Alice Forbes Perkins Hooper, 1910-1932 (San Marino, Calif., 1970), p. 396; Bentinck-Smith, Building a Great Library, pp. 115-20.

13. Bentinck-Smith, Building a Great Library, p. 108; HUA, Coolidge letter to Lewis Einstein, November 23, 1926; Einstein letters to Coolidge, December 27, 1926; February 1, 1927; Boris Bakhmeteff letter to Coolidge, January 9, 1925; Coolidge letter to Michael Karpovich, January 3, 1927; Coolidge letter to Robert J. Kerner, June 27, 1927; Coolidge letter to Sir Bernard Pares, March 22, 1927; Council on Foreign Relations Archives, Coolidge letter to Hamilton Fish Armstrong, January 28, 1927; Armstrong letter to Coolidge, January $31,1927$. 
structor for five years, a commitment later extended to $1903 .{ }^{14}$ Wiener introduced elementary Russian, and then advanced Russian, Polish, and other Slavic languages, as well as Russian and Polish literature. He thus established on a high level the base on which Harvard later constructed its Department of Slavic Languages and Literatures.

Late in Wiener's years at Harvard, when that genius but "essentially quarrelsome man" was approaching retirement, Coolidge paid Samuel H. Cross -whom Wiener considered his most brilliant student-to teach a course on Poland, Bohemia, and the Slavic peoples. Cross had received his B.A. from Harvard in 1912 and his Ph.D. in 1916. He spent four years in the army and six years in the Department of Commerce, first in the Netherlands and Belgium, then as chief of the European division of the Bureau of Foreign and Domestic Commerce, before going into business in Boston and continuing his research in the evenings. When Wiener retired in 1930, Cross succeeded him, thereby ensuring continuity in Slavic languages and literatures. Just before his death in January 1928, Coolidge wrote with pride to Sir Bernard Pares that Harvard had nine faculty members and offered twenty-one semester courses in the Slavic field. ${ }^{15}$

Coolidge's interest in promoting research and instruction in Slavic languages and literatures had other profound effects. As a friend of George Lyman Kittredge, the great Shakespeare scholar, and of other specialists in literature and folklore, Coolidge became acquainted with their outstanding students, particularly those who developed a secondary interest in Russian literature. One whom Coolidge helped was George R. Noyes, who received his Ph.D. from Harvard in 1898 with a thesis on Dryden and then went to St. Petersburg for two years to learn Russian and to develop competence in Russian literature. After 1901, Noyes and Henry Morse Stephens, Coolidge's closest friend in the historical fraternity, cooperated to develop the Department of History and the Slavic field at the University of California at Berkeley, both of which were expanded by Kerner after his arrival in 1928. That same year, Ernest J. Simmons, impressed by Coolidge and "things Russian" when he was a Harvard undergraduate, followed Noyes's path by obtaining his Ph.D. in English literature with a thesis on the history of the folk tale and then going to Moscow on a Harvard fellowship to begin his fruitful career in the field of Russian literature. ${ }^{16}$

Coolidge's interests were not limited to the Slavic field. In 1909, for example, he taught the first course in Asian history at Harvard. Despite other obligations,

14. Norbert Wiener, I Am a Mathematician (Garden City, N.Y., 1956), pp. 28-30, 45; Bentinck-Smith, Building a Great Library, pp. 11-12; HUA, Coolidge letter to President Charles William Eliot, November 6, 1903; Harvard Corporation agreement, October 9, 1903; University of California, Bancroft Library, Coolidge letter to Robert J. Kerner, August 23, 1924.

15. HUA, Coolidge letters to Samuel H. Cross, April 30 and May 3, 1927; Cross letter to Coolidge, June 3, 1927; Samuel H. Cross, Competitive Factors in Selling to Belgium and the Netherlands (Washington, D.C., 1925) ; Samuel H. Cross, "Pouchkine en Angleterre," Revue de littérature comparée, 17 (January-March 1937) : 176.

16. Oleg Maslenikov, "Biographical Sketch and Bibliography of G. R. Noyes," in Alexander Kaun and Ernest J. Simmons, eds., Slavic Studies (Ithaca, N.Y., 1943), p. 229; John Caughey, Hubert Howe Bancroft: Historian of the West (Berkeley, 1946), pp. 357-65; Albert Parry, America Learns Russian (Syracuse, 1967), pp. 53-55; Ernest J. Simmons, "A Wayward Scholar," unpublished manuscript, 1970, pp. 4-6. 
he continued that course until the early 1920s, because he thought "it would be even more shameful to have Harvard offer no instruction at all in the Far East." Coolidge then underwrote a lectureship in Far Eastern history for five years. $\mathrm{He}$ was responsible for beginning the library's collection in the Chinese field, and was one of the founders of the Harvard-Yenching Institute in $1928 .{ }^{17} \mathrm{He}$ also sponsored Latin American history, by pressing the appointment of Roger B. Merriman, who joined the department in 1902, taught the first course in Spanish history in 1903, and introduced Latin American history in 1907. Coolidge later helped obtain funds from a former student and later eminent diplomat, Robert Woods Bliss, for a chair in Latin American history, to which the department ultimately appointed another of Coolidge's History 1 assistants, Clarence Haring. ${ }^{18}$

Coolidge's interests were not restricted to the history of the so-called nonWestern areas. Aware that American history taught at Harvard had an Eastern flavor, in 1909 he persuaded. Lowell to make an appointment in Far Western history by agreeing to pay Frederick Jackson Turner's salary for his first five years at Harvard. He then persuaded Turner to join the Harvard faculty. For ten years, he intensively supported Turner's efforts to develop the Harvard Commission on Western History. Later, when Turner retired, Coolidge helped convince Arthur M. Schlesinger to take his place. ${ }^{19}$

Coolidge sought "to increase the fresh air" at Harvard by teaching abroad and by helping to bring foreign scholars to the university. Thus, he taught in Paris in 1906-7 and in Berlin in 1913-14. These ventures, like his shorter summer trips, not only increased his knowledge of other universities and scholars, but also advanced the reputation of Harvard in other countries, a goal he considered essential.

He was especially active in bringing foreign scholars into the Harvard community, especially those interested in Russia and Eastern Europe. These included Josef Redlich and Alfred Pribram from Vienna in 1910 and in 1927, respectively; Charles Diehl from Paris in 1911 and again in 1927; Father Aurelio Palmieri and George LaPiana from Rome before the First World War and in 1920, respectively; and H. A. L. Fisher, George M. Trevelyan, Harold Temperley, Robert Seton-Watson, and Charles K. Webster from England, at various times. All of these men gave Harvard students and faculty some of the

17. Paula Cronin, "East Asian Studies at Harvard. A Scholarly Bridge between two Worlds," Harvard Today, Spring 1976, pp. 8-9; Wilbur H. Siebert, "Collections of Materials in English and European History and Subsidiary Fields in the Libraries of the United States," Annual Report of the American Historical Association for the Year 1904 (Washington, D.C., 1905), p. 662; Harvard-Yenching Institute, A Guide to the Chinese-Japanese Library of Harvard University (Cambridge, Mass., 1932), pp. 5-8; Bentinck-Smith, Building a Great Library, pp. 161-62; Coolidge and Lord, A. C. Coolidge, p. 48; Council on Foreign Relations Archives, Coolidge letter to Hamilton Fish Armstrong, September 11, 1925; HUA, Coolidge letter to Stanley Hornbeck, June 23, 1926.

18. HUA, Coolidge letters to Ellis Morgan, June 7, 1913, April 15, 1914; Coolidge letter to Charles Crane, February 3, 1921; Bentinck-Smith, Building a Great Library, p. 161.

19. Ray Allen Billington, Frederick Jackson Turner (New York, 1973), pp. 298-300, 310; Billington, Dear Lady, pp. 15-26, 53-69, 103, 115-62, 210, 304-5, 359, 396-98, 423-24; Arthur M. Schlesinger, In Retrospect. The History of a Historian (New York, 1963), pp. 74-75; Bentinck-Smith, Building a Great Library, pp. 115-20; HUA, Ellery Sedgwick letter to Coolidge, November 25, 1924; Coolidge letter to Sedgwick, November 26, 1924. 
knowledge and insights Coolidge thought essential, and they also served in effect as publicity agents for Harvard when they returned to their institutions. ${ }^{20}$

The library remained central for Coolidge, who recognized early that "a great university can hardly exist without a good library." Within a year after his appointment as director of the library, he outlined a long-term program, arranged for a business management review, and asked architects to prepare plans for a new library building. Coolidge and President A. Lawrence Lowell began to seek funds for the building in January 1912. They were therefore prepared with plans four months before Harry Elkins Widener, Harvard class of 1907, went down with the Titanic. Coolidge helped Lowell persuade Widener's mother to contribute approximately three million dollars for the construction of Widener Library as a memorial to her son. Widener has remained a source and a symbol of Harvard's greatness for more than sixty years.

Coolidge's concerns extended beyond building and improving the collection. Early on he recognized the importance of a highly qualified and dedicated library staff. As a "generous and thoughtful commanding officer," he helped to create a team of able men and women, largely by communicating his enthusiasm and by sharing both the special plans and the routine chores, even to moving books out of the old library on a Sunday. He devoted much of his first five years as director to reorganizing the classification system and the catalogs. The latter task included substituting three million Library of Congress catalog cards for Harvard's old and small ones, and more than fifteen years of the steady process of making new cards of the correct size for those volumes for which neither the Library of Congress nor the John Crerar Library provided substitutes, a project for which Coolidge provided the funds.

His most obvious contribution came through his own imaginative purchases and gifts. It is difficult to determine the magnitude of Coolidge's benefactions before his final bequests, but his financial contributions to the library approximately equaled the salary he received from Harvard from 1893 through 1928. He gave somewhat more than one hundred thousand dollars for the purchase of books alone. In some years, the books Coolidge gave the library constituted more than 20 percent of the new titles and the dollar contribution was half the amount Harvard made available from university funds for book purchases. ${ }^{21}$ In addition, he contributed substantial funds for cataloging the volumes he donated. From 1905 through 1915, he paid the salary and travel expenses of Walter Lichtenstein (who received his Ph.D. in 1907) while Lichtenstein traveled throughout Europe and Latin America purchasing books for the library.

Although Widener Library was the major Harvard recipient of his generosity, Coolidge also made an annual donation to the endowment fund; during the last decade of his life this amounted to five thousand dollars, at a time when his

20. Das politische Tagebuch Josef Redlichs, vol. 1: 1908-1914, vol. 2: 1915-1919 (Graz and Cologne, 1953-54), $1: x v i$; Council on Foreign Relations Archives, Coolidge letters to Hamilton Fish Armstrong, April 12, April 21, June 22, 1923; August 15, 1924; HUA, Coolidge letters to President A. Lawrence Lowell, June 7, 1922; to Charles K. Webster, May 8, 1926; to Alfred Pribram, May 14, June 22, 1927; to William L. Langer, March 29, 1927 ; Pribram letter to Coolidge, May 6, 1927.

21. Bentinck-Smith, Building a Great Library, pp. 11-14, 42-43; Coolidge and Lord, A. C. Coolidge, p. 87. 
salary was eight thousand dollars. He also paid the salaries of Wiener, Turner, Cross, and a number of other faculty members during the first few years of their service, which led to permanent appointments for these men.

Coolidge's first major contribution to the library was the entire Slavic section of the Harrassowitz bookstore in Leipzig, which he visited on his way to Central Asia in 1895. This collection contained 1,371 titles, at a time when Harvard possessed about the same number of volumes in Slavic history, and added a total of about 15,000 volumes a year to its holdings.

Four years later, Coolidge persuaded his father to purchase 3,000 volumes on Ottoman history and the Eastern Question. The following year, Coolidge, together with his father and friends, donated to the university the library of Count Paul Riant in Paris-7,349 volumes and 1,200 pamphlets on the Crusades and the Latin East. This collection, which cost $\$ 10,735$ (of which Coolidge contributed $\$ 3,750$ ), was the most valuable gift the library had received until that time. In 1901, he purchased the Alexander Lombardini collection on Slovak history and literature, which Wiener had discovered on a trip in Eastern Europe and which remains the core of Harvard's resources on Slovakia. ${ }^{22}$ And, in 1904, when Harvard had only a thousand volumes on German history, Coolidge promised to add ten thousand volumes on German and Scandinavian history, in honor of the visit of Prince Henry of Prussia in 1902. He purchased the library of Professor Konrad von Maurer in Munich as the first step toward this Hohenzollern collection, and employed Lichtenstein to travel through Germany to purchase the remaining volumes. Later, Coolidge made extensive purchases in Russian art history.

When he was in Vienna in 1919, Coolidge managed to collect four thousand volumes on Central Europe. Similarly, he purchased three thousand five hundred volumes in Moscow in 1921-22, largely dealing with law and the theater. He also arranged for Golder to sell to Harvard any duplicates obtained for the Hoover collection. He was eternally active in persuading friends, relatives; and former students, especially those in business or in the Foreign Service, to contribute special collections. ${ }^{23}$

Finally, Coolidge introduced book collecting to two other great benefactors of Harvard: Bayard L. Kilgour, Jr., of the class of 1927, whom Coolidge and Blake had interested in Russia and in book collecting, gave Harvard his substantial collection of first editions of Russian poets and novelists. Even more impor-

22. Otto Harrassowitz Buchhandlung und Antiquariat in Leipzig, Antiquarischer Catalog 202: Slavica, Sprachwissenschaft, Literatur, Geschichte und Ethnographie des slavischen Völker (Leipzig, 1895); Count Paul Riant, Catalogue de la bibliothèque de feu M. le comte Riant rédigé par L. de Germon et L. Polain, 3 vols. in 2 (Paris, 1896-99), 2: page opposite title page; Dmitry Cizevsky, "The Slovak Collection of the Harvard College Library," Harvard Library Bulletin, 7, no. 3 (Autumn 1953): 299-300, 311; Charles R. Gredler, "The Slavic Collection at Harvard," Harvard Library Bulletin, 17, no. 4 (October 1969): 431; Stanford Shaw, "The Harvard College Library Collection of Books on Ottoman History and Literature," typescript, Cambridge, Mass., 1959, preface; George P. Winship, "Archibald Cary Coolidge," Harvard Library Notes, no. 20 (April 1928), pp. 158-60; Bentinck-Smith, Building a Great Library, pp. 11-15, 42-43; Coolidge and Lord, A. C. Coolidge, p. 87.

23. "The Russian Books," Harvard Library Notes, no. 9 (December 1922), pp. 203-7; Laurence E. Gelfand, The Inquiry: American Preparations for Peace (New York, 1963), pp. 55-56; Herbert Hoover, An American Epic, 4 vols. (Chicago, 1959-64), 3:454-55; Paul Miliukov, Memoirs, 1905-1917, ed. Arthur P. Mendel (Ann Arbor, 1967), p. 190; Lucius M. Beebe, Boston and the Boston Legend (New York, 1935), p. 205; HUA, Coolidge letter to Golder, February 24, 1923. 
tant, partly because of Coolidge, Robert Woods Bliss, Harvard class 'of 1900 and a close friend of Coolidge as an undergraduate and throughout his diplomatic career, began the collection in Byzantine history which led to the Dumbarton Oaks Library and Center for Byzantine Studies. ${ }^{24}$

In December 1894, Coolidge presented the first paper dealing with Russian history at an annual meeting of the American Historical Association. In it, he urged American historians to cease their neglect of northern Europe and Russia, "because anything connected with the development and conditions of such a mighty Empire is obviously worthy of attention." Coolidge noted that Russia's inhabitants "are a gifted people destined to play more and more a leading part in the history of mankind." In addition, he called for Americans to study Russia, Poland, and Scandinavia because of the significance of their folklore and drama, and because such analysis could illustrate the importance of geography, reveal the different roles religions and nationalities play, and demonstrate how different systems of government had developed over centuries among neighboring peoples. The paper attracted much attention; it was published in the second volume of the American Historical Review in April 1896 and was also reprinted in the association's annual report. ${ }^{25}$

From 1897 until 1910, Coolidge served as the American Historical Review's principal commentator on Russian and East European history, especially on volumes written in French, German, and Russian. He then stepped aside so that his former students, and others, could enjoy the same opportunity. During Coolidge's tenure on the Review's Board of Editors (1920-24), the journal published four articles on Russia, as many as it had on Russia and Eastern Europe together during its first twenty years. ${ }^{26}$

Coolidge also helped organize the first meeting of American historians interested in Russian and East European history. The session-a luncheon at the Association's conference at Richmond, Virginia, on December 30, 1924-brought together about one hundred fifty men and women from twenty-nine universities, many high schools, and a number of embassies and government departments in Washington. Coolidge and Kerner made the arrangements and Coolidge chaired the meeting, which was designed to dramatize the progress, define the principal needs, and underline the wisdom of working with scholars from other countries, especially the Soviet Union and England. Michael Rostovtsev of the University of Wisconsin, who had been a professor in St. Petersburg, gave the principal paper: "The Main Lines of Development of Modern Historical Scholarship in Russia." Other papers were presented by Seton-Watson of the University of London, on the future of Slavic studies, and by Golder, on the present status of historical studies in Russia. The commentators were Samuel Harper of Chicago,

24. Harvard College Library, The Kilgour Collection of Russian Literature, 1750-1920 (Cambridge, Mass., 1959), preface; Emerton and Morison, "History," p. 170. Coolidge and Bliss were frequent correspondents and Coolidge often visited the Blisses in Washington and in embassies abroad.

25. Archibald Cary Coolidge, "A Plea for the Study of the History of Northern Europe," American Historical Association, Anmual Report, 1895 (Washington, D.C., 1896), pp. 44351 ; reprinted in American Historical Review, 2, no. 1 (October 1896) : 34-39.

26. Archibald Cary Coolidge, "Russia in Asia: A Record and a Study, 1588-1899, by Alexis Krausse," American Historical Review, 5, no. 2 (December 1899): 345-47; American Historical Review, 2, no. 2 (January 1897) : 351-53; American Historical Review, 21, no. 1 (October 1915) : 194; Coolidge and Lord, A. C. Coolidge, p. 33. 
Kerner of Missouri, Geroid T. Robinson of Columbia, and Sir Bernard Pares of London. ${ }^{27}$

The 1924 luncheon represented the peak of American historians' interest in Russia and Eastern Europe until after World War II. The program, the participants, and the list of those present show that the study of Russia and Eastern Europe had spread throughout much of the United States and had interested many nonspecialists. American and British scholars cooperated closely, were interested in the entire Slavic world, and were concerned with the work of Soviet scholars. In 1924, in part because of the correspondence which led to this luncheon meeting, the Slavonic Review in London added three Americans-Harper, Kerner, and Lord-to its editorial board as evidence that the journal should serve both communities and that scholars in the two countries should work together. However, Coolidge's belief that dedicated individuals could do everything and his successful opposition to Kerner's and others' efforts to establish a national organization in 1924 seriously hampered the development of Russian studies during this critical time.

Coolidge did not confine his teaching to Harvard. For example, he gave the Lowell Institute Lectures in Boston on the expansion of Russia (1902), and on the new states of Central Europe (1920). He presented series of lectures at the University of Virginia, Northwestern University, and the University of Chicago, and he also gave occasional lectures at other institutions at a time when this practice was far less common. Between 1893 and 1903, he published thirtyone articles in The Nation, four of which were devoted to Russia, two to Poland, and six to the Balkans. During the same period, he contributed sixty-two book reviews, twelve of which were on Eastern Europe and the Near East. From late 1919 through 1921, he published twelve leading articles in the New York Evening Post, which was then being edited by his friend and colleague, Edwin F. Gay. Coolidge was also active in establishing and directing the Institute of Politics in Williamstown, Massachusetts, an impressive summer school program in international politics which flowered from 1921 to 1932 . He helped President Garfield and his colleagues to identify and attract outstanding statesmen and scholars, particularly from Europe, to participate in round tables and to give lectures. Russia and Eastern Europe naturally occupied a central position in these programs, and Coolidge often participated. ${ }^{28}$

Coolidge's main contribution to increasing knowledge and understanding among an important group of informed citizens was his service as editor of Foreign Affairs during its first six years of publication. His impact on Foreign Affairs was so profound that the patterns he established still survive, even in

27. HUA, Coolidge letters to Sir Bernard Pares, May 20, June 9, 1924; Pares letters to Coolidge, July 14, 1923; March 2, May 11, 1924; University of California, Bancroft Library, Coolidge letters to Kerner, June 12, June 24, September 12, 1924; Library of Congress, Manuscript Division, J. Franklin Jameson Papers, Pares letter to Jameson, June 24, August 4, 1924; "The Meeting of the American Historical Association at Richmond," American Historical Reviewe, 30, no. 3 (April 1925): 451, 458-59; Robert J. Kerner, "Slavonic Studies in America," Slavonic Review, 3 (December 1924): 242 and 258; "The Slavonic Conference at Richmond," Slavonic Review, 3 (March 1925) : 684-93.

28. Arthur Howland Buffinton, "The Institute of Politics," in Harry A. Garfield, Lost Visions (Boston, 1944), pp. 273-75;.Walter W. McLaren, "The Institute of Politics," in E. Herbert Botsford, ed., Fifty Years at Williams, 4 vols. (Pittsfield, Mass., 1928-40), 4: 149-63; HUA, Coolidge letters to McLaren, May 4, 1922; May 19, 1923; McLaren letters to Coolidge, January 25, January 29, 1924. 
the system of notices given to new books, the format and style, the quality of the paper, and the color of the cover.

In Coolidge's words, Foreign Affairs sought "to promote the discussion of current questions of international interest and to serve as the national medium for the expression of the best thought, not only of this country, but of Europe. . . ." The journal published articles which were "competent and well-informed, representing honest opinion, seriously held and convincingly expressed. . . ." Emphasizing "broad hospitality to divergent ideas," Foreign Affairs under Coolidge and his successors did not accept "responsibility for the views expressed in any article," but did accept responsibility "for giving them a chance to appear there." 29

Coolidge showed penetrating insight and judgment in identifying critical issues and great skill in persuading outstanding scholars and statesmen from every part of the world to contribute essays. From the beginning, he was determined to devote a great deal of attention to Russia and Eastern Europe. During his years as editor, he published essays by statesmen such as Eduard Beneš and Tomáš G. Masaryk from Czechoslovakia, and Count István Bethlen from Hungary. He obtained articles from Boris Bakhmetev, the ambassador to Washington from the Provisional Government of Russia, from Victor Chernov, the leader of the Socialist Revolutionaries, and from scholars such as Seton-Watson, Pares, Temperley, and Redlich. He encouraged Americans such as Lord, Kelley, and Haskins to discuss contemporary issues in the light of history. He made a number of efforts to obtain contributions from Soviet leaders, particularly Radek and Krassin, whom he had met in 1921-22, but, except for Christian Rakovskii, he was not successful in his attempts, even though Lenin and his colleagues were avid readers of the journal. Indeed, Lenin was one of many observers who paid tribute to Coolidge's remarkably objective and farsighted article in the journal's first issue in September 1922, "Russia after Genoa and the Hague." During the six years during which Coolidge was editor, Foreign Affairs published fiftythree articles on Russia and Eastern Europe. His managing editor and successor, Hamilton Fish Armstrong, followed this practice: in its first forty-five years, Foreign Affairs published 248 articles on the Soviet Union, about one-eighth of all the essays which appeared during that period. ${ }^{30}$

Coolidge also contributed toward promoting Russian studies by demonstrating to government officials the quality of mind that scholars could bring to the study of contemporary international problems, and by helping to define the relationships which should exist between the government and the scholarly community. His knowledge of Germany persuaded him that American scholars must remain independent of the government, functioning as independent analysts and critics and working for the government directly only in times of national emergency. His only official services were rendered during and immediately after the First World War. He helped establish the Inquiry and served on it from October 1917 through May 1, 1918. In fact, the Inquiry was almost entirely a

29. Foreign Affairs, 1, no. 1 (September 1922): 1; Coolidge and Lord, A. C. Coolidge, pp. 306-11.

30. Council on Foreign Relations Archives, Coolidge letters to Armstrong, June 4, July 11, September 9, September 26, October 2, December 11, December 13, 1922; January 3, April 7, 1923; February 1, 1926; Armstrong to Coolidge, February 7, 1926; Coolidge to Karl Radek, March 23, 1927; Archibald Cary Coolidge, "Russia after Genoa and The Hague," Foreign Affairs, 1, no. 1 (September 1922): 133-55; Armstrong, Peace and Counterpeace, p. 192. 
Harvard affair: the majority of the research staff were Harvard professors or Harvard graduates and Widener Library served as the base for the work done on Russia and Eastern Europe, which naturally occupied a central role. ${ }^{31}$

In May 1918, as a special assistant to the secretary of state and a member of the War Trade Board, Coolidge traveled to Scandinavia and to Murmansk and Archangel to collect information concerning economic and commercial conditions in Russia. He then went to Paris as a member of the American Commission to Negotiate Peace and to Vienna as chief of the mission from January through May 22, 1919. The 285 reports he forwarded to Paris from Vienna on the boundary problems in Eastern Europe and the need for "guaranteed rights for minorities" were models of informed and objective clarity. In fact, the boundaries established for Poland, Hungary, Czechoslovakia, and particularly Austria would have been more permanently acceptable if the leaders in Paris had considered the information and accepted the views of Coolidge and his colleagues.

Finally, Coolidge served in the Soviet Union from October 27, 1921 through March 1, 1922 as the chief of the Liaison Division, or political adviser, of the American Relief Administration, which helped to feed fifteen million starving Russians during those years. Coolidge accepted this appointment from Herbert Hoover for the American Red Cross, and in fact used his sabbatical leave for it, because both he and Lowell thought it an important obligation. Moreover, Coolidge correctly anticipated that he would learn a great deal about the new regime and conditions in Russia, which would be helpful in his teaching. He concluded immediately that the new government faced almost insuperable problems, but that it would survive because its leaders were so capable and because they controlled the army and the police. ${ }^{32}$

It is, of course, difficult to measure precisely the contributions Coolidge made toward establishing a sound basis for the professional study of Russia and Eastern Europe in the United States. Sooner or later, in one way or another, someone would have offered the first course, made the first plea for increased attention, interested the universities and the American Historical Association in this neglected area of the world, and begun to train young scholar-teachers. Harvard would have introduced Russian studies and probably would have established a great library without Coolidge, and the Council on Foreign Relations and Foreign Affairs would have come into existence without his participation. However, Coolidge not only launched Russian and East European studies in the United States, he deeply affected the foundations of this field of study. First, in identifying some of the major needs of the university and in remedying those shortcomings, often by judicious use of his own money, he recognized the proper priorities--beginning with undergraduate education, faculty resources, and li-

31. Gelfand, The Inquiry, pp. 54-56, 321, 340; James T. Shotwell, The Autobiography of James T. Shotwell (Indianapolis, 1961), p. 78; Coolidge and Lord, A. C. Coolidge, pp. 19293; HUA, Coolidge papers, Inquiry Folder, especially Coolidge, "The Inquiry: Report of A. C. Coolidge for January 15, 1918."

32. HUA, Coolidge, "Reports from A. C. Coolidge to the American Commission to Negotiate Peace"; Coolidge letters to his mother, May 18, July 31, August 14, September 4, 1918; Archibald Cary Coolidge, "Report to the Secretary of State: Archangel," September 28, 1918; Archibald Cary Coolidge, "Archangel and Murmansk: Report for the War Trade Board," n.d.; Hoover Institution, American Relief Administration Archives, John A. Lehrs, "Report of the Liaison Division," n.d.; Herbert Hoover letter to Coolidge, August 9, 1921; Gelfand, The Inquiry, p. 108; Coolidge and Lord, A. C. Coolidge, pp. 170-91, 217-33, 270303. 
brary-before introducing graduate programs. He appreciated the fact that a strong language and literature department was essential and that high standards for language training were vital. He realized that Russia was only one of the foreign areas American universities neglected, and he led or joined efforts to create resources in other areas. His greatest capacity, however, was his ability to identify outstanding future scholar-teachers. His judgments were almost unerring: the careers of Cross, Lord, Karpovich, Langer, and Wiener at Harvard reflect this uncanny attribute.

Coolidge was also active in the American Historical Association and in other forums, through which he increased American knowledge and understanding of Russia and Eastern Europe and of international politics. He cooperated willingly with other universities, even with Yale. He continually reminded his students and the profession of the international boundaries of their studies. $\mathrm{He}$ set a standard of independence, from the government in particular, that helped keep American teaching and research free from outside influence while making these strengths available during emergencies.

Coolidge's greatest contribution consisted in the high professional standards he established in the formative stage of this field of study. Indeed, as the Harvard faculty statement noted after his death, a passion for intellectual quality was his only prejudice. He tried to remain free from politics and to explain, not to condemn. He sought to be, and generally was, cool, balanced, and fair. Starting with his first year, he urged that "Russian history should be viewed in just as cool and commonplace a fashion as that of any other country and its phenomena examined just as calmly." He encouraged Americans to recognize the biases built into the cultural framework in which they lived. Thus, he sought to explain why Anglo-Saxon Protestants found Russian Orthodox Christians difficult to understand; he compared Ivan the Terrible with Cavour, Yermak with Cortés, Russian policy in the Balkans in 1877-78 with American policy toward Spain twenty years later. His judgments, in seminars, in revolutionary Budapest in 1919, and in Moscow in 1921-22, were objective and hard-headed.

Coolidge's standards are most evident in his selection of colleagues and graduate students and in his training requirements. He emphasized that all scholars in the Russian field should master Russian, French, and German. He insisted that his students understand the society and the culture of the peoples in whom they were interested. He devoted substantial attention to geography, climate, demography, government, and religion, but his neglect of economics, music, and the arts contributed to the slow development of these fields. He required extensive and prolonged travel of his graduate students, and also helped make opportunities for travel available. The East European peoples were just as important and probably even more interesting for him than their neighbors to the east or west, and he recognized that they deserved just as careful study as did the Russians or the French. Finally, he insisted that Russia and Eastern Europe were a part of Europe and that Russia was also a part of Asia ; therefore, all scholar-teachers should understand the wider European, Asian, and even international frameworks of which their subjects were a part. In short, Coolidge strongly resisted pressures toward narrow specialization and helped provide solid and broad foundations precisely at a time when the United States was emerging as a world power and the American people needed to increase their knowledge and understanding of their new circumstances. 